\title{
Determinant of customers' preference in selecting Islamic banks
}

Irwan Shahrinaz, Jati Kasuma *, Abang Sulaiman Abang Naim, Emelia Abdul Rahim, Arrominy Arabi, Norlelawati Ismawi, Rosmiyati Rosli

Faculty of Business Management, Universiti Teknologi MARA, 94300 Kota Samarahan, Sarawak, Malaysia

\section{A R T I C L E I N F O}

\section{Article history:}

Received 6 November 2016

Received in revised form

7 January 2017

Accepted 11 January 2017

\section{Keywords:}

Islamic banking

Customer preferences

Religion

Service quality

Friends and family

\begin{abstract}
A B S T R A C T
The presence of conventional bank and Islamic bank in Malaysia has created a competition in capturing customer. Customer of Islamic bank maintained their account with the bank if they are satisfied with the product and services offered to them. Other research reveals that the reasons for Muslim to choose Islamic banking are mostly due to religious concern and motives. This study investigates the relationship between religions; influence by family and friend and finally service quality with customers' behavior towards bank selection preferences. Data was collected from 380 customers using selfadministered questionnaires from various Islamic banks in Miri. Results reveal that service quality and preference of choosing Islamic bank in Miri has a strong and positive relationship. Ultimately, friends and family has more impact towards preference in choosing Islamic bank. Recommendation for future study also discussed.
\end{abstract}

(C) 2017 The Authors. Published by IASE. This is an open access article under the CC BY-NC-ND license (http://creativecommons.org/licenses/by-nc-nd/4.0/).

\section{Introduction}

Introduced near 1970s, the financial institution based on Islamic laws was pioneered by Egypt, Indonesia and Malaysia. The main purpose of Islamic banking is to reshape the existing banking principals of financial services and products within the mold of Islamic principals in order to satisfy the demands and requirements of customers, especially the religious conscious ones. Based on existing studies, most Muslims choose Islamic Banking based on their beliefs in Islamic principles concerning trade as compared to general people that are based on logical reasons to choose their desired financial institution. Aside from profit maximization and other conventional benefits, obeying Islamic principles are also the reason for them to choose Islamic Bank. Such can be said that their decisions to choose Islamic banking are based on their emotions and behaviors that are associated with their religion which can be considered as behavioral financing. Within the banking industry in Malaysia, the presence of conventional banks and Islamic banks creates competition in capturing customer. By offering quality in their products and services to replace interest based product, Islamic banking

\footnotetext{
* Corresponding Author.

Email Address: jati@sarawak.uitm.edu.my (J. Kasuma) https://doi.org/10.21833/ijaas.2017.03.018

2313-626X/C 2017 The Authors. Published by IASE.

This is an open access article under the CC BY-NC-ND license

(http://creativecommons.org/licenses/by-nc-nd/4.0/)
}

manages to attract a large number of customer. Customer of Islamic bank maintained their account with the bank if they are satisfied with the product and services offered to them. Other research reveals that the reasons for Muslim to choose Islamic banking are mostly due to religious concerns and motives. The customer psychological state of mind is the main reason for them to act on a line satisfaction when choosing a bank. The research was carried out in Miri, Sarawak as a second largest city in Sarawak consisting of Malay, Chinese, Iban, Orang Ulu and other indigenous groups. Thorough our extensive literature analysis, it was found that, the study regarding Islamic banking has yet to be published for this area and this information manages to trigger the interest of carrying out this research. Presently, there are two local full fledge Islamic bank in Miri which are Bank Islam as well as Bank Muamalat. Also, there are other foreign bank like OCBC, HSBC and some other dual system which combines conventional as well as Islamic banking concept. The need to understand customer behavior towards Islamic banking is important as the competition between banking industry is becoming intense.

The purpose of this study is to explore the preference of customer towards Islamic bank by using religion, influence of family and friends and service quality to find out which variables is powerful enough to influence customer choice towards Islamic bank in Miri, Sarawak, Malaysia. This will consequently lead to customer satisfaction which would reflect the future potential of Islamic 
banking in Malaysia. The ultimate outcome of this research is to find out the customers preference in selecting the Islamic bank in Miri. Objectives of this study are (1) to examine the relationship of religion, influence of friends and family and service quality towards preference of Islamic bank in Miri and (2) to determine which independent variables has tremendous impact toward preference of Islamic bank in Miri.

\section{Literature review}

\subsection{Religion}

The Islamic market is Shariah ${ }^{\dagger}$ compliant. Shariah is an Islamic canonical law based on the teachings of the Koran and the traditions of the Prophet (Hadith and Sunna), prescribing both religious and secular duties and sometimes retributive penalties for law breaking. It has generally been supplemented by legislation adapted to the conditions of the day. Islamic laws state that customers are allowed to utilize and manages all resources available on the earth without being luxurious as Islam doesn't appraise luxurious or lavish life style. Islamic customer prefers Islamic banking rather than conventional banking since Islamic bank follows Islamic views and teaching. Religion does not just lie in its capacity for differentiation of people, it also lies in its ability to structure and lend meaning to everyday, to the local world of interaction. At the same time, Islamic banking came into existence to satisfy the financial needs of Muslims who have to observe the prohibition of interest based transactions (Haq and Smithson, 2003). Banks who operates on sharia have a good reputation in gaining their clients confidence by conducting their operation on sharia principles and secrecy of information (Subhani et al., 2012).

\subsection{Service quality}

The quality of services offered by banks regardless conventional or Islamic must be of high quality in order to attract customer and also to satisfy them. This would be the dream of every business existed. According to Rehman and Shabbir (2010), religion play important role in shaping people knowledge, attitudes and beliefs as well as it impact on customer decision and action because it enlighten them about things that are prohibit and not prohibit. For the past few decades, Islamic banking had grown very well due to the increasing demand of better service quality and the need to improve. Customer have knowledge and they know what they are capable of, thus pushed Islamic banking to flourish and overcome conventional banking (Ahmad and Hassan, 2007). With the growth rate of 25-20\% annually, Islamic banking shows great potential to surpass conventional

\footnotetext{
$\dagger$ Sharia is the religious law governing the members of the Islamic faith.
}

banking, even though there are only two large Islamic banks in Miri, there are several conventional bank that had offered dual financial system in order to capture the Muslim's market.

Akram et al. (2011) concluded that the efficiency and performance of Islamic banking increases due to the competition between the conventional and Islamic banking in banking sectors. Even though Islamic banking faces more challenges, still they are growing and performing better which then leads towards improvements. Ali et al. (2011) managed to identify the important factors that attract and satisfy customers which are bank image, bank offering financial benefits to customers, customer care, service quality and bank competitiveness. Shabbir el al. (2012) examined that the factor for growth in banking sector of Pakistan is high quality services which leads to customer satisfaction, customer retention, customer loyalty, reduction of customer complaint and efforts for improvement in service quality. Factors like customers' satisfaction trust and customer perception has a direct influence on customer loyalty. Higher customer loyalty arrives from high customer satisfaction and positive customer perception about Islamic banks. When customers are satisfied that Islamic bank are dealing according to Islamic Norms and values by having no element of interest in its dealing, it will create loyalty.

\subsection{Family and friends}

Family and friends are considered as the most influential group for immediate reference and potential decision making influencer for customer. With family consisting of parents and siblings, they provide basic knowledge and understanding on religion, politics and economics, sense of personal ambition, self-worth and love (Awan and Azhar, 2014). Even if interaction between customer and their parents is still ongoing or not, influence on behavior can be significant. Aside from parents, Awan and Azhar (2014) mentioned that most customer belong into some "Friendship Groups" that is a specific customer reference group which are generally termed, informal groups, unstructured without or lack of specific authority levels. Plenty of studies shown that customer's decision making process in selecting Islamic Bank were influenced by family advice typically father and mother with their innate religious belief and motivation (Wangenheim and Bayón, 2004; Grace and O'Cass, 2003; Razzouk, 2004; Ettenson and Turner, 1997). Hegazy (1995) studied on bank selection criteria for both Islamic banks and commercial banks which then leads to a conclusion that the most important factor attributes for Islamic banks was the advice and recommendations made by family and friends. A study carried out by Jati et al. (2015) concluded that positive word of mouth and evaluation about a certain product by family members and friends will motivate customer to end up with the same opinion towards that product. 


\subsection{Customer's preferences}

Abundance of literature with regards to financial products and services criteria existed today since it had been heavily studied over the past two decades (Metawa and Almossawi, 1998). Among the areas studied and attributes found are relatives' advice and recommendations, friends' advice and recommendation availability of credit, variety of bank services, availability of ATM, convenient location, the quality of services, adequate bank hours, return on investment, friendliness of personnel, understanding financial needs, special services for women and bank name. Dusuki and Abdullah (2006) found that customer preference often depends on the quality of services provided by Islamic banks. Metawa and Almossawi (1998) revealed that adherence to Islamic tenets is the main motivating factor for customers to preferring Islamic banks in Bahrain.

\section{Methodology}

\subsection{Research design and framework}

The purpose of this research is to determine relationship between religions, influence by family and friend; and service quality with customer preference in selecting Islamic Bank. Finally, figuring out which of these variables has more impact on this relationship (Fig. 1).

\subsection{Data collection and analyses}

Data are collected through a self-administered questionnaire distributed by hand to the banks customers. The questionnaire was categorized in two sections. Section one included the demographic information of the customer (gender, age, academic qualification, income, marital status, occupation). Section two includes information regarding the customers dealing with Islamic Banks in accordance with religion, family and friends influence and service quality. Questionnaire consists of three questions related to religion, five questions about friends and family responses and three questions covering service quality aspects. Descriptive methods are used to describe behavioral data in general and some inferential analysis is performed to understand the relationship among variables.

\section{Results and discussion}

\subsection{Respondent's profile}

A total of 400 questionnaires were distributed and 380 are usable. Out of the 380 respondents in the study, $54.5 \%$ are females and $45.5 \%$ are males. $75.6 \%$ of respondents are Malay followed by Iban with $18.2 \%$, Orang Ulu with $2.8 \%$ and Chinese with $3.4 \%$. Majority of customers are married $61 \%$ as compare to unmarried which is $39 \%$. Majority of customer have income level of RM2,000-RM4,999 with $51.5 \%$ as compared to below RM2,000 with $30 \%$ and the remaining $18.5 \%$ belong to income group above RM5,000.

\subsection{Findings}

\subsubsection{First research objective}

First research objective is to examine the relationship of religion, influence of friends and family and service quality towards customer preference of Islamic bank in Miri.

Three separated analysis were carried out in order to identify the precise results for each independent variable. The first analysis included the correlation between religion and customer preference. The second analysis is between family and friends influence towards customer preference. Finally, the third analysis was between service quality and customer preference.

In Table 1, Pearson's $r$ is 0.772 . This number is close to 1 . For this reason, it can be concluded that there is a strong relationship between religion and preference variables. Aside from that, Pearson's $r$ was shown as positive which indicates that as one variable increases in value, the second variable also increase in value and as one variable decrease in value, the second variable also decrease in value. Based on the result, it is proven that religion and preference of choosing Islamic bank in Miri has a strong and positive relationship.

Table 1: Analysis based on religion and customer preference

\begin{tabular}{cccc}
\hline & & Religion & Preference \\
\hline \multirow{2}{*}{ Religion } & Pearson Correlation & 1 & $0.772^{* *}$ \\
& Sig. (2-tailed) & & 0.000 \\
& N & 380 & 380 \\
Preference & Pearson Correlation & $0.772^{* *}$ & 1 \\
& Sig. (2-tailed) & 0.000 & \\
& N & 380 & 380 \\
\hline \multicolumn{4}{c}{ N Correlation is significant at the 0.01 level (2-tailed) }
\end{tabular}

Since the Sig (2-Tailed) value is less than or equal to 0.05 ( $p<0.01)$ we can conclude that there is a statistically significant correlations between the two variables. That means, increases or decreases in one variable do significantly relate to increases or decreases in the second variable. This finding is supported by a study of Metawa and Almossawi (1998) where they reveals that adherence to Islamic tenets is the main motivating factor for customers to preferring Islamic Banks. That means the customers 
are actually more incline towards preferring Islamic Bank due to religion conscience. Aside from that, another study carried out by Haque (2016) also supported that there are significant relationship between religion and customer preference. In the study, they discussed about market segmentation based on customer's levels of religiosity.

In Table 2, Pearson's $r$ is 0.866 . This number is very close to 1 .

Table 2: Influence of family and friend and customer preference

\begin{tabular}{cccc}
\hline & & Family and Friends & Preference \\
\hline \multirow{3}{*}{ Influence of Family and friends } & Pearson Correlation & 1 & $0.866^{* *}$ \\
& Sig. (2-tailed) & 380 & 0.000 \\
& $\mathrm{~N}$ & & 380 \\
& & $0.866^{* *}$ & 1 \\
Customer Preference & Pearson Correlation & 0.000 & 380 \\
& Sig. (2-tailed) & $\mathrm{N}$ & 380
\end{tabular}

For this reason, it can be concluded that there is a strong relationship between family and friends and preference variables. Aside from that, Pearson's $r$ was shown as positive which indicates that as one variable increases in value, the second variable also increase in value and as one variable decrease in value, the second variable also decrease in value. Based on the result, it is proven that family and friends and preference of choosing Islamic bank in Miri have a strong and positive relationship. Since the Sig (2-Tailed) value is less than or equal to 0.05 ( $p<0.01$ ), we can conclude that there is a statistically significant correlations between the two variables. That means increases or decreases in one variable do significantly relate to increases or decreases in the second variable. This result concur with study carried out by Hegazy (1995) on bank selection criteria for both Islamic banks and commercial banks concluding that the most important factor attributes for Islamic banks was the advice and recommendations made by family and friends.
In Table 3, Pearson's $r$ is 0.690 . This number is close to 1 . For this reason, it can be said that there is a strong relationship between service quality and preference variables. Aside from that, Pearson's $r$ was shown as positive which indicates that as one variable increases in value, the second variable also increase in value and as one variable decrease in value, the second variable also decrease in value. Based on the result, it is proven that service quality and preference of choosing Islamic bank in Miri has a strong and positive relationship. Since the Sig (2Tailed) value is less than or equal to 0.05 ( $p<0.01$ ), we can conclude that there is a statistically significant correlations between the two variables. That means, increases or decreases in one variable do significantly relate to increases or decreases in the second variable. This means that the positive influence from service quality will leads to positive preference of Islamic bank in Miri. Thus, this finding answered one of the research objectives which are to determine the relationship between service quality and preference of Islamic bank.

Table 3: Service quality and preference

\begin{tabular}{cccc}
\hline & & Service Quality & Preference \\
\hline \multirow{2}{*}{ Service quality } & Pearson Correlation & 1 & $0.690^{* *}$ \\
& Sig. (2-tailed) & & 0.000 \\
& $\mathrm{~N}$ & 380 & 380 \\
& & \\
Preference & Pearson Correlation & $0.690^{* *}$ & 1 \\
& Sig. (2-tailed) & 0.000 & 380 \\
\hline & $\mathrm{N}$ & 380 &
\end{tabular}

\subsubsection{Second research objective}

Second research objective is to identify which independent variables has a tremendous impact toward preference of Islamic bank in Miri.

The $\mathrm{r} 2$ is 0.503 explaining that $50.3 \%$ of changes in the dependent variable value (preference) can be explained by the independent variables included in the regression equation (religion, influence of friends and family, service quality). This means that the remaining $49.7 \%$ of $\mathrm{r} 2$ can be explain by other factors that are not discussed in this study.

The standardized coefficient that was obtained is represented as beta. These are the coefficients that are obtained once all of the variables in the regression are standardized, including the dependent and all of the independent variables, and ran the regression.

By standardizing the variables before running the regression, all of the variables were put on the same scale and can be compared with the magnitude of the coefficients to see which one has more of an effect. Based on the Table 4, the highest number under Beta column would be 0.433 for friends and family. As compared to the other independent variables (religion and service quality) with the Beta result of 0.205 and 0.096 respectively, it is clearly shown that friends and family with 0.433 has more impact towards preference. Thus, answering the research Objective 2 to identify which independent variables has more impact towards preference of Islamic banking. 
A study carried out by Jati et al. (2015) concluded that positive word of mouth and evaluation about a certain product by family members and friends will motivate customer to end up with the same opinion towards that product. This result also concur with study carried out by Hegazy
(1995) on bank selection criteria for both Islamic banks and commercial banks concluding that the most important factor attributes for Islamic banks was the advice and recommendations made by family and friends.

Table 4: Summary of coefficient

\begin{tabular}{|c|c|c|c|}
\hline \multirow{2}{*}{ Model } & Standardized Coefficient & \multirow[b]{2}{*}{$\mathrm{t}$} & \multirow[b]{2}{*}{ Sig. } \\
\hline & Beta & & \\
\hline Constant & & 0.299 & 0.766 \\
\hline Religion & 0.205 & 2.419 & 0.017 \\
\hline Friends and family & 0.433 & 5.906 & 0.000 \\
\hline Service quality & 0.096 & 1.372 & 0.172 \\
\hline
\end{tabular}

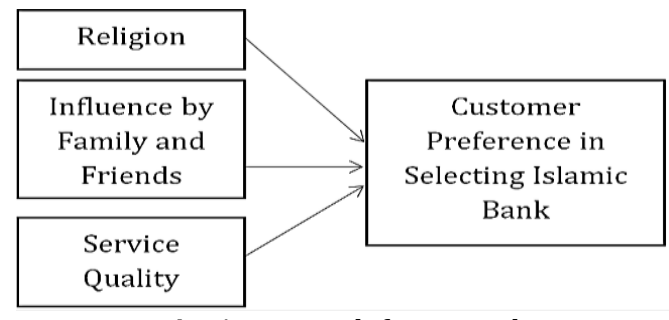

Fig. 1: Research framework

\section{Conclusion}

The results of the present study show that all the three dimensions (religion, influence of friends and family and service quality) can be used to predict the customer preference of Islamic bank in Miri. Among the three variables, influence of friends and family is found to be the most important factor of customer preference in selecting Islamic bank in Miri. The importance of recommendations or word-of-mouth in the formation of attitudes in a service purchase decision making context has been discussed in many studies, especially in professional services. Many studies showed the decision making process of Islamic banks users were affected by spouses, friends and relatives as their innate religious motivation. Thus, influence by the friends and family is the priority in the preference of Islamic bank.

\section{References}

Ahmad AUF and Hassan MK (2007). Regulation and performance of Islamic banking in Bangladesh. Thunderbird International Business Review, 49(2): 251-277.

Akram M, Rafique M, and Alam HM (2011). Prospects of Islamic banking: Reflections from Pakistan. Australian Journal of Business and Management Research, 1(2): 125-134.

Ali K, Akhtar MF, and Ahmed HZ (2011). Bank Specific and Macroeconomic Indicators of Profitability - Empirical Evidence from the Commercial banks of Pakistan. International Journal of Business and Social Science, 2(6), 235 $-242$.

Awan A and Azhar M (2014). Customer Behavior towards Islamic Banking in Pakistan. European Journal of Accounting and Finance Research, 2(9): 42-65.
Dusuki A and Abdullah NI (2006). Why do Malaysian customers patronize Islamic Banks? International Journal of Bank, 25(3): 142-160.

Ettenson R and Turner K (1997). An exploratory investigation of consumer decision making for selected professional and nonprofessional services. Journal of Services Marketing, 11(2): 91-104.

Grace D and O'Cass A (2003). Child care services: An exploratory study of choice, switching and search behaviour. European Journal of Marketing, 37(1/2): 107-132.

Haq MF and Smithson S (2003). The role of IS in Islamic banking: A cultural perspective. In the Proceedings of European Conference on Information Systems (ECIS '03), Naples, Italy: 1-7.

Haque Z (2016). Religiosity and Indian customer preferences: An empirical study. Imperial Journal of Interdisciplinary Research, 2(4): 1085-1094.

Hegazy I (1995). An empirical comparative study between Islamic and commercial banks selection criteria. International Journal of Islamic Financial Services, 5(3): 3-11.

Jati K, Melissa L, Agnes K, and Hawa N (2015). Antecedents of consumer behavior and foreign product evaluation among consumer. Journal of Scientific Research and Development, 2(14): 19-25.

Metawa SA and Almossawi M (1998). Banking behavior of Islamic bank customers: Perspective and implications. International Journal of Bank Marketing, 16(7): 299-313.

Razzouk N (2004). What's important in choosing a primary care physician: An analysis of consumer response. International Journal of Health Care Quality Assurance, 17(4): 205-211.

Rehman AU and Shabbir MS (2010). The relationship between religiosity and new product adoption. Journal of Islamic Marketing, 1(1): 63-69.

Shabbir MF, Aslam DH, Capusneanu S, Barbu CM, and Tanveer MA (2012). Perceived service quality of Islamic and non-Islamic banks operating in Pakistan. American Journal of Scientific Research, 51: 27-36.

Subhani MI, Hasan SA, Rafiq MF, Nayaz M, and Osman A (2012). Consumer criteria for the selection of an Islamic bank: Evidence from Pakistan. International Research Journal of Finance and Economics, 94: 114-122.

Wangenheim FV and Bayón T (2004). The effect of word of mouth on services switching: Measurement and moderating variables. European Journal of Marketing, 38(9/10): 11731185. 